\title{
Investigations of Apartment House Cellar Microclimate and It's Improvement Possibilities
}

\author{
Stanislavs Pleiksnis \\ Rezekne Technology Academy \\ Rezekne, Latvia \\ stanislavs.pleiksnis@inbox.lv
}

Sandra Gusta

Latvia University of Life Sciences and

Technologies

Jelgava, Latvia

sandra.gusta@1lu.lv

\author{
Edmunds Visockis \\ Latvia University of Life Sciences and \\ Technologies \\ Jelgava, Latvia \\ ems@1lu.lv
}

\author{
Raimunds Selegovskis \\ Latvia University of Life Sciences and \\ Technologies \\ Jelgava, Latvia \\ raimunds.selegovskis@1lu.lv
}

\begin{abstract}
Apartment houses made in the last century in Latvia have rather big heat transfer factor and not good ventilation, especially in cellar. That leads to formation of condensate on building constructions. During cold weather in winter time, this condensate formats ice layer that damages building constructions ant also lead to inconvenience for inhabitants, for example, disturbs opening of cellar door.
\end{abstract}

During investigations the cellar microclimate parameters, such as temperature, humidity and dew point, were measured and different ways to improve them and as result preventing of condensate formation were worked out.

The measurements shows that sometimes the air temperature and the temperature on surfaces reaches dew point and therefore the condensate starts to format.

The possibilities to eliminate humidity and to increase dew point are worked out during investigations. doors

Keywords-energy efficiency of buildings, heat insulated

\section{INTRODUCTION}

Currently rebuilding (insulation) many apartment buildings on the walls strengthens heat insulation. Windows are mostly replaced only old Soviet times, uses 2 glass packages, only rarely are used most energy efficient with 3 glass packs, exterior doors are not heat insulated. The overall energy performance of buildings is not so high improvement as it could be achieved by focusing on the other essentials [1].

Energy efficiency improvement do not provide for renovation of several essential elements of the building, such as repair or replacement of cold water supply and sewerage, power supply, fire protection system. Evaluating these systems for major defects or preemergency situations will allow building owners to decide on the appropriate renovation works. [2]

The Bali conference heard repeated calls for reductions in global greenhouse gas emissions of 50 per cent by 2050 to avoid exceeding the $2^{\circ} \mathrm{C}$ threshold. While such endpoint targets dominate the policy agenda, they do not, in isolation, have a scientific basis and are likely to lead to dangerously misguided policies. To be scientifically credible, policy must be informed by an understanding of cumulative emissions and associated emission pathways. [3]

There needs to be better awareness and understanding of the energy options available, including their real impact on emissions, their real costs and the impact of pricing. In pursuing the sustainable energy future, we need to balance near-term achievables with long-term imperatives. [4]

Embodied energy and carbon dioxide emissions will become more significant as operational energy consumption is reduced. In the near future, embodied energy could account for a significant proportion of a building's carbon footprint over its lifetime, bearing in mind that the construction of energy-efficient buildings is carbon and energy intensive. [5]

In the south of Finland, about 50 kilometers from the capital, Helsinki, is the small town of Porvo. The city is located in an industrial region, but the ambition of the Porvo municipality is not lacking - it is about to become one of the first cities in Finland to completely free itself from the harmful carbon emissions, thus fighting climate change. Porvere's vice mayor says that when building new buildings, care should be taken to make it more energy efficient, while old houses can be upgraded, for example, by heat insulation so that they do not lose heat in winter. Fon Scholz recalls that the extra heat generated by the heat loss of the building also produces additional harmful emissions. [6]

Within the framework of the scientific research of the publication, the possibility to use additional doors with increased thermal resistance is studied. The construction of the insulated door made of $10 \mathrm{~mm}$ thick veneer sheets in wooden frame with the inside protects from warm and humid air with $50 \mathrm{~mm}$ thick moisture-resistant foam polyester and $100 \mathrm{~mm}$ thick mechanically resistant facade stone wool on the outer side, which provides fire safety.

Print ISSN 1691-5402

Online ISSN 2256-070X

http://dx.doi.org/10.17770/etr2019vol1.4185 (C) 2019 Stanislavs Pleiksnis, Edmunds Visockis, Raimunds Selegovskis, Sandra Gusta. Published by Rezekne Academy of Technologies.

This is an open access article under the Creative Commons Attribution 4.0 International License. 
Together, it forms an appropriate heat-insulating material composite that fulfills all the physical-mechanical, building norms requirements and significantly raise energy-efficiency of cellar spaces.

\section{Material and methods}

To make necessary calculations for eliminating problems with condensation on the steel door surface, the measurements of temperatures and humidity were carried out during winter period of 2018 from 29th January to $12^{\text {th }}$ February.

The measurements were performed by HOBO loggers H08-007-02. The main paramet4ers are given in Table 1.

Table1. Parameters Of Logger Hobo

\begin{tabular}{|l|l|c|}
\hline No. & Parameter & Range \\
\hline & Operating range & $-20^{\circ} \mathrm{C}$ to $+70^{\circ} \mathrm{C}$, \\
1. & $\begin{array}{c}\text { (logger): } \\
-\quad \text { Temperature }\end{array}$ & $\begin{array}{c}05 \% \mathrm{RH} \text { non- } \\
\text { condensing }\end{array}$ \\
& $-\quad$ Humidity & approx. \pm 1 minute per \\
week $( \pm 100$ ppm at \\
2. & Time accuracy: & $\left.+20^{\circ} \mathrm{C}\right)$ \\
\hline 3. & Responsetime: & about 15 minutes \\
\hline
\end{tabular}

One measuring device was situated on inside surface of the steel door (Fig.1.a) the second on inside surface of inner doors to cellar (Fig.1.b.).

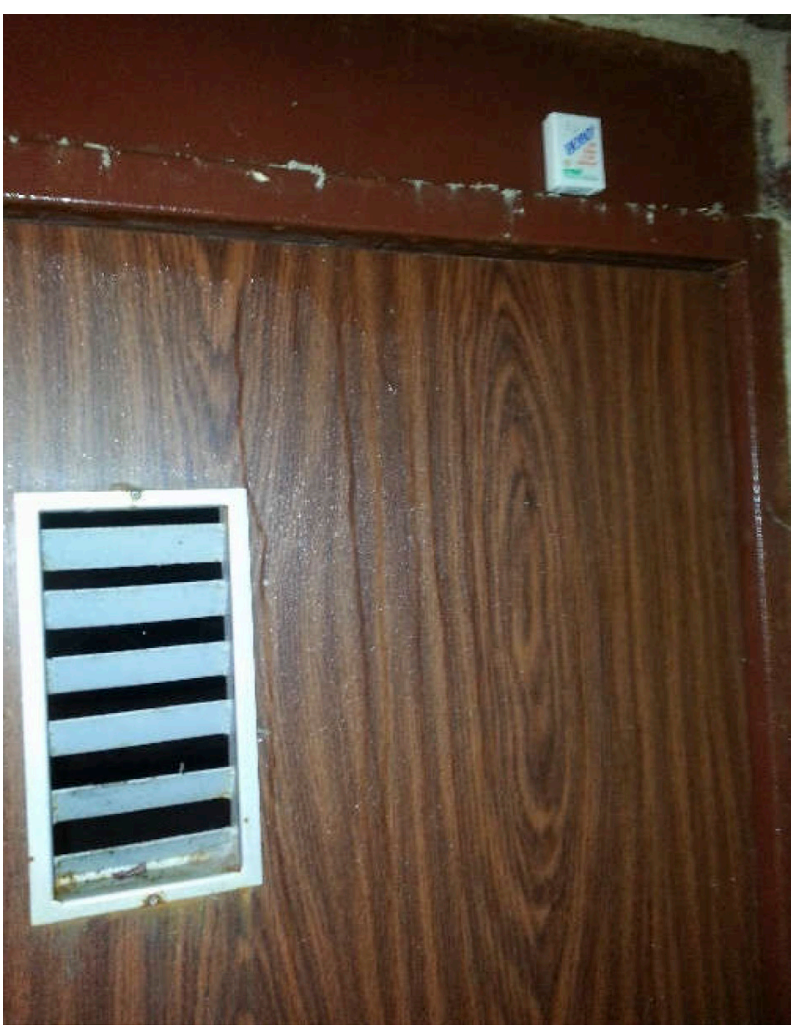

a - outside steel door

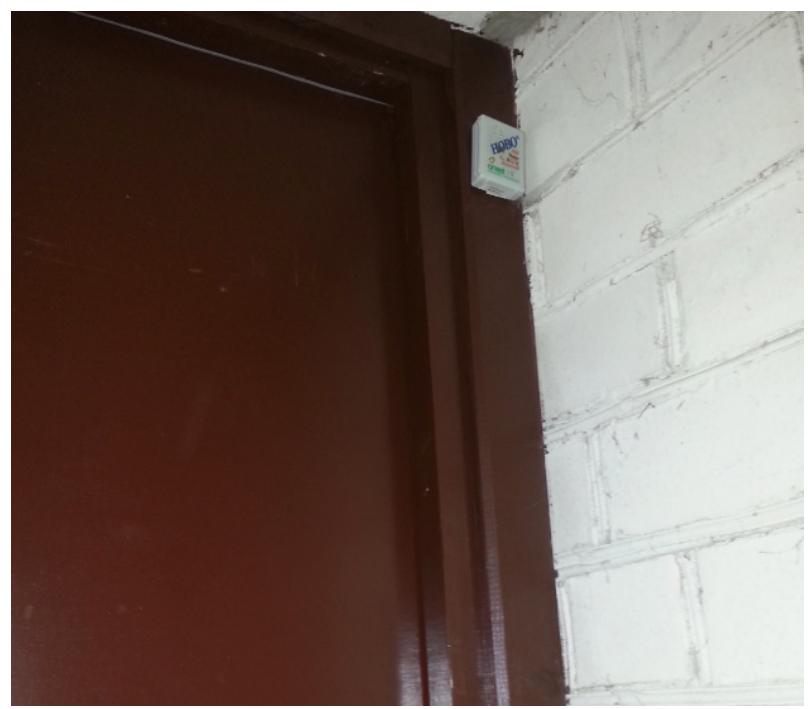

$\mathrm{b}$ - inside wooden door

Fig.1. Location of measuring devices

During measurements it was carried out, that sometimes the dew point is reached (Fig.2) that explains the formation of the condensate on the steel doors inner surface. This is the place, where warmer air with high humidity from cellar side meets the more cool door's surface. When the temperature falling below zero, the condensate starts to freeze.

\section{Results and discussions}

Temperature and Dew Point 31 Jan-01 Feb 2018

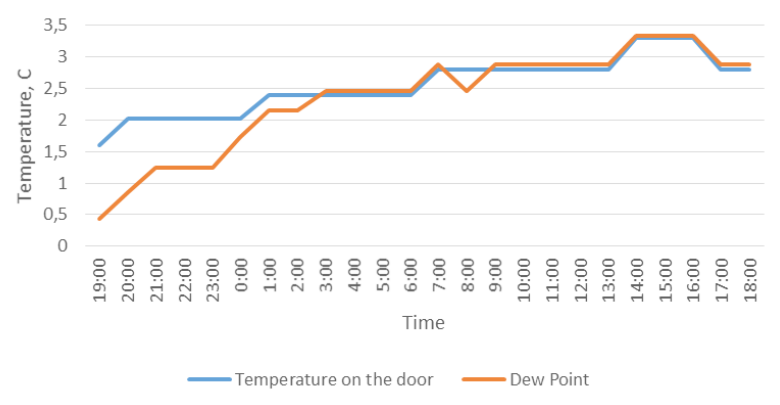

Fig.2. Temperature on the steel door and dew point

There are several methods to eliminate the formation of condensate. One of them is to prevent contact of wet warmer air from cellar with low temperature door surface. The solution is represented in Fig.3.

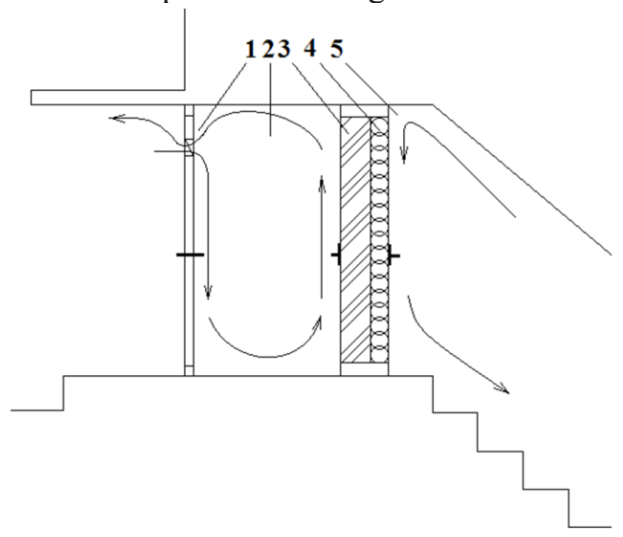

Fig.3. Solution with inner door heat insulation

1 - steel door with ventilation opening, 2 - space between two doors, 3 - rock wool insulation layer in outer side of the wooden door, 4 polystyrene inside insulation layer, 5 - stair space to cellar. 
The placing of door with heat insulation keeps the temperature on inner door above dew point and save the heat, but the ventilation opening in the steel door takes away the humidity from space between two doors. The warm water don't meet the outdoor surface.

Results of measurements established, that the lowest temperature behind the steel door during measuring period in January and February 2018 was $-3{ }^{\circ} \mathrm{C}$.

The highest dew point was established $4{ }^{\circ} \mathrm{C}$ (that don't diverges in time with mentioned temperature, but there are rated the extreme values).

The average temperature of cellar air is approximately 6-7 ${ }^{0} \mathrm{C}$. The heat flow density if there is dew point temperature $4{ }^{\circ} \mathrm{C}$ on insulated door inner surface, is calculated by following:

where:

$$
q=\alpha_{i n} *\left(t_{c}-t_{d i}\right)=8,7 *(6-4)=17,4,
$$

$q$ - heat flow density from cellar air to door surface,

if temperature on surface is equal with dew point, $\mathrm{W}^{*} \mathrm{~m}^{-2}$

$\alpha_{\text {in }}$ - the heat transfer factor for inside surface of inside door, $\mathrm{W}^{*} \mathrm{~m}^{-2 * 0} \mathrm{C}$;

$\mathrm{t}_{\mathrm{c}}$ - average cellar air temperature, ${ }^{0} \mathrm{C}$;

$\mathrm{t}_{\mathrm{di}}$-temperature on door inner surface, ${ }^{0} \mathrm{C}$.

The heat insulation of the door have to be such, that heat flow density through the door will not exceed calculated value, is:

$$
R \geq \frac{t_{d i}-t_{d 0}}{q}=\frac{4-(-3)}{174}=0,4,
$$

where:

$\mathrm{R}$ - thermal resistance of the door, $\mathrm{m}^{2 * 0} \mathrm{C}^{*} \mathrm{~W}^{-1}$,

$\mathrm{t}_{\mathrm{di}}$ - average cellar air temperature, ${ }^{0} \mathrm{C}$;

$\mathrm{t}_{\mathrm{do}}$ - temperature of air in the space between door, ${ }^{0} \mathrm{C}$.

Therefore, if the rockwool will be used as the heat insulation of the door, the thickness of wool layer have to be more than approximately $2 \mathrm{~cm}$.

This type of insulated door significantly reduces heat loss from basement spaces, protects external doors from icing and freezing, improves comfort conditions on the ground floor of the apartment building because the floor is considerably warmer and significantly improves the overall heat consumption balance of the building in the long time. The use of such doors is recommended to be included in the energy efficiency improvement measures of buildings in order to prevent heat loss from the point of view that has not been addressed so far.

\section{Conclusions}

1. Additional heat insulated door provide protection of cellar hot and wet air condensate on outside steel door and freezing to save possibility that open in all times.

2. Additional heat insulated door save significant amount of heat in to inside of building that way increase energy efficiency of building and also save heat energy expenses.

3. Ground floor of the apartment building is considerably warmer and significantly improves comfort of living.

\section{REFERENCES}

[1] Building law of Latvia [Online]. Available: http://www.likumi. lv/doc.php?id=36531 [Accessed: Jan. 3, 2019]

[2] VA Housing Agency. Study. Analysis of energy efficiency status of multi-apartment residential houses and recommendations for its improvement. - Riga: VA Housing Agency, 2007-30 p.

[3] Anderson K. un Bows A.; Reframing the climate change challenge in light of post-2000 emission trends; [Online]. Available: http://rsta.royalsocietypublishing.org/content/366/1882/3863. full?sid=e3cd44d4-5713-4441-b1d6-5cc632a4243c [Accessed: Jan. 10, 2019]

[4] Armstrong L.; Towards a sustainable energy future: realities and opportunities; [Online]. Available: http://rsta.royalsocietypublishing.org/content/369/1942/1857.full?sid=c6168ae5-6127-

48c2-9c50-3bb77d77008a [Accessed: Jan.15, 2019]

[5] Assessing embodied energy of building structural elements; [Online]. Available: http://www.icevirtuallibrary.com/content/

article/10.1680/ensu.2010.163.3.147 [Accessed: Feb. 3, 2019]

[6] The success story of the Finnish city in the fight against climate change, which not only inspires citizens [Online]. Available: https://www.tvnet.lv/6565567/somijas-pilsetas-veiksmes-stasts-cina-pret-klimata-parmainam-kas-iedvesmo-ne-tikai-iedzivotajus. [Accessed: Apr. 11, 2019] 